\title{
Türk edebiyatında Bizans imparatoriçeleri ve Selim İleri’nin “Hepsi Alev" romanı
}

\section{Dilek Yeliz MAKTAL CANKO1}

\begin{abstract}
APA: Maktal Canko, D. Y. (2019). Türk edebiyatında Bizans imparatoriçeleri ve Selim İleri’nin "Hepsi Alev" romanı. RumeliDE Dil ve Edebiyat Araştırmaları Dergisi, (16), 308-166. DOI: 10.29000/rumelide.618931

"Gözyașı döktüm. Kendim için. Teodora’nın küçülüşleri için. Çünkü Bizans’a hükmetmiş... Gözyaşı döktüm binlerce gözyaşı. Ama neye yarar?”
\end{abstract}

Selim İleri, Hepsi Alev

\section{$\ddot{\mathbf{O} z}$}

Türk edebiyatında güzel, alımlı, mert, cesur, işveli, şehvetli ve vefasız Bizanslı kadınların popüler tarihi romanlarda temsillerine karşılık; Bizans imparatoriçeleri biyografik romanlarda karşımıza çıkmaktadır. Bu makalede beş yazarın üç Bizans imparatoriçesi hakkındaki biyografik romanları incelenmiştir. Bu romanların; tarihi kaynaklarla paralel bilgiler içermelerine karşılık; eserlerin yazıldığı dönemin ideolojisinden de etkilenmiş oldukları açıktır. Tespit edilen en erken tarihli eser 1946 yılına aittir ve imparatoriçe Irene'yi konu alır. İmparatoriçe Irene 2007 yllında Selim İleri’nin Hepsi Alev romanının da başkahramanıdır. Türk ve Dünya edebiyatında hakkında en çok biyografik roman yazılan imparatoriçe Teodora ise biri üç ciltlik olmak üzere iki esere konu olmuştur. İmparatoriçe Eudokia ise bir eserde karşımıza çıkmıştır. 1920-1970 yılları arasında yoğun bir şekilde beliren popüler tarihi roman furyasında popüler bir dil sergileyen yazarlar arasında Abdullah Ziya Kozanoğlu, Murat Sertoğlu, Kerim Sam ve Yakup Özdemir’in eserlerinde dönemin ulusçu yaklaşımının etkisi yoğun olarak hissedilmektedir. Selim İleri’ye kadar olan tüm bu eserler Bizans imparatoriçelerini, Bizans İmparatorluğu için yaptıklarından ziyade bir kadın olarak dış görünüşlerinin güzelliği - ki onlar da abartılmıştır - acımasız, sert tarafları ve en önemlisi şehvet düşkünü, cinsellik tutkunu olarak tasvir edip dişilikleri ile ön plana çıkartmıştır. Türk edebiyatında ilk kez Selim İleri, Hepsi Alev romanı ile Bizanslı bir imparatoriçenin yaşadıklarına, başarılarına, acılarına, sevinçlerine, savaşlarına ve hüzünlerine odaklanmıştır. Bu makalede, Türk edebiyatındaki Bizans imparatoriçelerini konu alan romanlar incelenmiş ve bu romanlar arasında Hepsi Alev'in önemi tartışılmıştır.

Anahtar kelimeler: Bizans imparatoriçeleri, popüler tarihi roman, Selim İleri, Hepsi Alev.

\section{Byzantine empress in Turkish literature and Selim İleri's novel "Hepsi Alev"}

\begin{abstract}
Despite the representations of the most popular historical novels of Byzantine women who beautiful, charming, brave, courageous, lustful and unfaithful in Turkish literature; Byzantine empresses appear in biographical novels. This article examines the biographical novels of five authors about three Byzantine empresses. These novels; although they contain parallel information with historical sources; they were also influenced by the ideology of the period in which the work was written. The
\end{abstract}


earliest discovered work dates back to 1946 and concerns the Empress Eirene. In 2007, Empress Eirene was the protagonist of Selim İleri's Hepsi Alev novel. In Turkish and world literature, the most important biographical novel about the Empress Teodora is represented in two novels, one of which is three volumes. Empress Eudokia appeared in a novel. In the novels of Abdullah Ziya Kozanoğlu, Murat Sertoğlu, Kerim Sam and Yakup Özdemir among the writers who exhibited a popular language in the popular historical novel fury that appeared intensely between 1920-1970 are intensely felt influence of the nationalist approach of the period. All these works up to Selim Ileri have brought the Byzantine Empress to the fore with the beauty of their appearance, their brutal, hard sides and most importantly lustful, sexuality, and femininity as a woman rather than what they did for the Byzantine Empire. For the first time in Turkish literature, Selim İleri focused on the experiences, successes, sorrows, joys, wars and sorrows of a Byzantine empress with the novel Hepsi Alev. For this reason, in this article, biographical novels of Byzantine empresses in Turkish literature are examined and the importance of Hepsi Alev among these novels is discussed.

Keywords: Byzantine empress, popular historical novel, Selim İleri, Hepsi Alev.

\section{Giriş}

Toplumun yaklaşık yarısını oluşturan ve tamamını doğuran kadınlar, her zaman ve her koşulda edebiyat dünyasının önemli bir öznesi olmuştur. Tanzimat döneminden beri yaşanan Batılılaşma sürecinde değişimden en çok etkilenen ve değişimi en çok yansıtanlar kadınlar olmuştur. Topluma fayda sağlamak amacında olan Tanzimat romanı, değişmenin öznesi ve öncüsü olan kadın karakterler vasıtasıyla örnek olunabilecek bir model çıkarmak istemiştir (Özdarıcı Arslan, 2010, s. 367-368). Bu dönem yazarları kadınları "güzel, zarif, terbiyeli, görgülü, kültürlü, musikiden anlayan, ev idaresinde ve çocuk terbiyesinde bilgili ve başarılı, ailesine bağll, kocasına sadık, ciddi, vakur ve marifetli” gibi olumlu özellikler ile ön plana çlkarmışlardır (Has Er, 200o, s. 411). Cumhuriyetle birlikte gelen sosyal değişiklik, Türk edebiyatında kadınların hem duygusal hem de toplumsal yönleriyle işlenmesini sağlamıştır (Çeri, 1992, s. 330-331). Bu dönemde hane içindeki sorumluluklarını yerine getirirken kamusal alanda erkeğin gözetiminde olan kadın, çalışma yaşamına büyük mücadelelerden sonra girmiş, fabrikalarda ve hizmet sektöründe birçok eşitsizlik ile karşı karşıya kalmıştır. Kadınların dönem romanlarındaki temsilleri de büyük ölçüde bu değişimin örüntülerini taşımaktadır (Şeker, 2017, s. 642-651).

Cumhuriyetin ilk yıllarında en çok baskısı yapılan roman grubu olan popüler tarihi romanlar (Sağlık, 2002, s. 146), kadın temsillerinin yoğun olarak görülmesi ile dikkat çekmektedir. Büyük bir bölümü 1453 yılında Fatih Sultan Mehmet'in Konstantinopolis’i fethetmesine kadar aynı coğrafyayı paylaştığımız Bizans İmparatorluğu ile Türk devletlerinin münasebetini konu alan bu romanlar, 1923’ten sonra Türkiye Cumhuriyeti Devleti'nde geniş bir okuyucu kitlesine ulaşmıştır. Abdullah Ziya Kozanoğlu², Murat Sertoğlư3, Ragıp Şevki Yeşim4, Kemalettin Tuğcu5, Feridun Fazıl Tülbentçí ${ }^{6}$, Mustafa Necati Sepetçioğlu7 ve Yavuz Bahadıroğlu's'nun popüler tarihi romanlarında; mutlaka mert, yiğit bir Türk kahraman ${ }^{9}$ ve aşık olduğu Bizanslı kadın vardır. Güçlü, kuvvetli yenilmez Türk kahramanlarının aşık

\footnotetext{
Savcı Bey, 1931; Sarı Benizli Adam, 1932; Battal Gazi, 1946; Arena Kraliçesi 1964.

Bizansl Aspasya, 1960; Battal Gazi, 1967.

Bizanslı Beyaz Güvercin, 1964.

Bizans Ylkılıyor, 1972.

Sultan Yıldırım Beyazıt, 1947; İstanbul'un Fethi, 1954.

Kilit, 1971; Anahtar, 1973; Kapı, 1973.

Sunguroğlu Bizans Saraylarında, 1975, Turgut Alp, 1989.

Bu dönem popüler tarihi romanlarda ulus kimliğinin inşası Türk kahramanlar ile güçlendirilmeye çalışılmıştır (Milllas 2000, 83).
} 
olduğu Bizanslı kadınlar güzel, alımlı, mert, cesur, şehvetli, vefasız kadınlardırº. Bizanslı kadınlar, cinsel bir çerçeve içinde betimlenirler, ailesine bağlı, iyi bir eş olan Bizanslı kadın neredeyse yoktur (Millas, 2000, s. 51-86). Bu romanlarda Türk-Müslüman kadınlar anadır, güçlüdür; dolayısıyla cinsellikten uzaktır. Bu durumda, "sevgili" rolü de yabancı kadınlara kalır (Belge, 2009, s. 43-44). Ancak yabancı kadınların sevgili rolünün amacı sadece üstlenilmeyen rol değildir. Şehvetli ve cilveli olan Bizanslı kadınların her zaman Türk erkeklerini tercih etmeleri, kendi milletlerine karşı Türkleri desteklemeleri ve Müslüman olmayı istemeleri Türklerin üstünlüğünü vurgulamak amaçlıdır (Millas, 2000, s. 91).

Yakın dönem tarihi ya da popüler tarihi romanlarda ise Türk cengaver-güzel Bizanslı kadın aşkı devam ederken, artık cinsellik ön planda değildir (Uğur, 2013, s. 299); ancak Bizanslı kadınların güzellikleri ve çekicilikleri devam etmektedir:

“...Bizanslı kadınlar buruk şarap tadındaymış. İlk kadehte başını döndürürlermiş insanın, ikicisinde adamakıllı sarhoş olurmuşsun. Üçüncüsünde yıkıldığın yerden kimse kaldıramazmış. Dördüncüsünde...” (Gürsel, 2012, s. 167)

Nedim Gürsel'in Boğazkesen (2003) isimli Fatih Sultan Mehmet'in Konstantinopolis’i fethetmesini konu edinen romanında ise Türk-Bizanslı kadın ilişkisinde farklı bir durum ortaya çlkar. "Eski seyir katibi Nicolo, Fatih Sultan Mehmet în içoğlan Selim”(169), zorla ele geçireceği Bizans'la özdeşleştirdiği beyaz bir kadın bedeni ister (209). Sultan Mehmet, Türk ordusunun Konstantinopolis’i üç gün yağmalamasına izin verdiği zaman Selim de şehrin içlerine dalar. Bir evin şarap mahzeninde beyaz tenli bir Bizanslı kızla karşılaşır ve yıllarca özlemini çektiği şeyi yapar, kıza saldırır. Ancak Selim, amacını gerçekleştiremeden sırtından tüm bedenine yayılan bir acı duyar. Kadının üçüncü hançer darbesinde yığılıp kalır kadının üzerine (216-218). Her ne kadar sonradan Müslüman olan bir yabancı olsa da Bizanslı kadın için Selim, Türk askeri kıyafetini giymiş ve Konstantinopolis’i yağmaya çıkmış bir Türk'tür. Bir Türk'ün bedenini kullanarak kendisini aşağllamasına izin vermez ve onu öldürür. Burada üstün gelen Bizanslı kadındır.

Gürsel Korat'ın 2010 tarihli 12. yüzyılda Bizans ve Anadolu Selçuklu dünyası arasında yaşanan Rüya Körü isimli romanında ise Bizanslı kadınlar; "beyaz tenli, hayranlık uyandıran menekşe gözlere (67) ve göz alıc güzelliğe (209) sahip", çekicidirler. Selçuklu beyinin torunu, saray yazıcısı Stefanos Aksukos ile İmparator I. Manuel'in yeğeni Andronikos, birinin rüyalarında geçmişi diğerinin geleceği görmesiyle bir rüya kardeşliği oluşturmuşlardır. Her ikisi de aynı kadına aşıktır: İmparator’un abisi Isaakios'un kızı Prenses Teodora'ya (54). Ancak Teodora birisini tercih eder: Bizanslı Andronikos'u (235).

Cumhuriyet döneminde, Türk insanına millet olma, ülkesini, tarihini sevme, aitlik hissetme bilinci vermeye çalışan dürüst, yardımsever, yenilmez, milli değerlerini her şeyin üstünde tutan kahramanlar ve onları her koşulda tercih eden Bizanslı kadınlar; Türklerin üstünlüğünü ortaya koymak ve okuyucuda milli duyguları perçinlemek amacındadır. Ancak yakın dönemde özellikle de 20ooli yıllardan sonra yayımlanan tarihi romanlarda Bizanslı kadınlar, cinsellikleri ile ön plana çlkmadıkları gibi Türk erkeklerini de tercih etmezler.

Bu dönem popüler tarihi roman yazarları cinsellikteki serbestliği vurgulayarak ötekini aşağılama yolunu seçer, biz ve
ötekiler ayrımını net biçimde ortaya koyarlar (Uğur 2013, 301-310). Bu da kadın karakterler yoluyla gerçekleştirilir. Kadınlar, ötekileştirme ve aşağılamanın aracı olmuşlardır. 
Türk edebiyatında ideolojik görüşler ile birlikte değişen Bizans kadını algısına Bizans imparatoriçeleri dahil edilmemiştir. Tarihi romanlarda çok az yer bulan Bizans imparatoriçeleri, daha çok biyografik romanlarda karşımıza çıkmaktadırlar.

\section{Türk edebiyatında Bizans imparatoriçeleri}

Batı'da Bizans imparatoriçelerinin büyüsüne kapılan ilk araştırmacı Paul Adams olmuştur. Adams, 1893 yılında Princesses Byzantines isimli kitabını yayımlayarak Bizanslı imparatoriçelerin önemine dikkat çekmiştir. Ardından Charles Diehl'in 1906 yılında yayımlanan Figures Byzantines isimli çalışması Bizans imparatoriçeleri hakkında çeşitli kaynaklarda yer alan öyküleri bir araya toplamıştır. Bu çalışmalardan sonra Bizans'ın güçlü ve gizemli kadınları olan imparatoriçeler hakkında çalışmalar ve yayınlar artan bir ilgi ile devam etmiştir (Canko, 2016, s. 3).

Batı yazınından kısa bir süre sonra Türk yazınında da Bizans İmparatoriçelerine ilgi başlamıştır. Türk yazınında Bizans İmparatoriçeleri hakkında ilk çalışma; tarihçi, şair ve yazar Ahmet Refik tarafından 1915 yllında Bizans İmparatoriçeleri ismiyle yayımlanmıştır. Ancak ne yazık ki aynı ilgi, Ahmet Refik'ten sonra devam etmemiştir.

Türkiye'deki popüler tarihçiliğin kurucusu ve en başarılı kalemi sayılan Ahmet Refik Altınay (1880?1937) (Sakaoğlu, 1993, s. 219) Bizans İmparatoriçeleri kitabında (2003), önsözünde de belirttiği gibi, Bizans tarihi ve medeniyeti hakkında Batıda yazılmış eserleri tam bir yetkinlikle yorumlayarak kullanmış ve yedi imparatoriçenin yaşamını okuyuculara açık ve kolay anlaşılır bir dille aktarmıştır.

"Hippodrom sahnelerinden Bizans tahtına yükselen, işvesi ve cazibesiyle gönülleri büyüleyen” Teodora (25); "ilim ve irfanı, güçlü şairliğiyle öne çıkmış" Atenayis (33); yüz güzelliğine sahip, iffetli bir kadın olan" İren (43); "kutsal tasvirlere ibadeti canlandırmaya teşebbüs etmiş, dindar" Teodora (60); "tabiatüstü güzelliğiyle üç imparatorun kalbini çalmış" Teofanu (65); "güzelliğine ve cazibesine son derece düşkün" Zoi (75) ve "Bizans'a fikri, kalemi, duyguları ve eserleriyle hizmet eden” Anna Komnena’nın (87) roman tadında yazılmış öykülerinde; imparatoriçelerin zekaları ve güzellikleri ile imparatorluğun siyasi ve idari işlerinde önemli görevleri yerine getirdikleri ve çoğu zaman tarihin gidişatını belirledikleri vurgulanmıştır. Altınay, eserinde Bizans imparatoriçeleri hakkındaki bilimsel bilgilere sadık kalmış, gerçekleri olduğu gibi aktarmaya özen göstermiştir.

Cumhuriyet döneminden itibaren ilgiyle okunan popüler tarihi romanlarda Bizans imparatoriçeleri, Bizans kadınları veya Bizans prenseslerine nazaran nadir görülür. Tüm Bizans kadınları gibi onlar da Türk kahramanlarından etkilenirler ancak olasılıkla imparatoriçe oluşları ve ağırlıkları her koşulda Türkleri tercih etmelerine engeldir: Yıldırım Beyazıt'ın Ankara Savaşı’nda öldüğü düşünülen oğlu Mustafa'nın (1421-1422) Sarı Yani ismi ile karşımıza çıtığı romanı Sarı Benizli Adam'da, "her Rum kadın gibi cilveli ve cana yakın olan" imparatoriçe, her ne kadar "kıvır kıvır kuvrandiran kuvvetli kolları, kendisinde arzu uyandırmış" olsa da Sarı Yani’nin ilgisini tersler (1964, s. 28). Bizans prensesleri ise bu romanlarda daha sık karşımıza çlkar ve onlar da Türk kahramanları tercih ederler. Türk Sultan’ı Murat Bey'in (1362-1389) taht için en uygun olan oğlu Savcı Bey'in, Bizanslı şehzade IV. Andronikos (1376-1379) ile arkadaşlı̆̆ı ve kardeşi Yıldırım Beyazıt'ın oyunları ile öldürülmesinin anlatıldığı Savcı Bey isimli romanda ise, Bizans prensesi Irene Kantekuzanos, Savcı Bey'e olan aşkı uğruna Bizans tahtından vazgeçerek sadık bir eş olmayı tercih eder. 
Ancak dönemin yazarları imparatoriçelerin de tüm Bizanslı kadınlar gibi vefasız oldukları konusunda israrcıdırlar:

"Bizanslı kadınlar çok vefasızdır. Altın kakmalı karyolasında uyuyan kocalarını düşmanlarının daha çabuk ve kolay boğabilmesi için kaleden Marmara sahiline ip bile sarkıtırlar. Sevgisinden öldükleri erkeğin arkadaşını daha kuvvetli daha edepsiz görürlerse - ki bu görüşlerinde hiç aldanmazlar hemen sevdiklerini bırakıp yenisine teslim oluverirler.” (Kozanoğlu, 1946, s. 152)

Kozanoğlu'nun bu satırlarında bahsettiği kadın, uyuyan kocasını kolay boğabilmesi için Marmara sahiline ip sarkıtan İmparatoriçe Theophano'dur. Güzelliği ile nam salan, iktidar uğruna kocasını aşığına öldürten imparatoriçe, Bizans İmparatorluğu tarihinde önemli olaylara da ismini yazdırmıştır. ${ }^{11}$

Türk edebiyatında Bizans imparatoriçeleri hakkındaki biyografik romanların ilki; Kerim Sam’ın 1946 yılında yayımlanan İmparatoriçe İren isimli eseridir. Sam’ın romanı, tarihi kayıtlar ile paralel hırslı, acımasız ve güçlü bir karakter sunarken ${ }^{12}$ İmparatoriçe Irene’ye şehvetli, entrikacı ve kendini beğenmiş sıfatlarını da abartarak yakıştırmıştır:

\begin{abstract}
"Kadın bu... Süs, ihtişam ve dekorun ikizi gibi dünyaya gelmiş mahluk eline geçirdiği saltanatı, debdebe ve şaşaayı kaçırmaktan korktuğu için çok hassas ve vehimli davranıyordu. Onun korkutan bir istila değil, hakimiyetinin gideceği, saltanatının öleceği idi." (84) “İren, kendini bazen bir mabut yavrusu zannedecek kadar gurur duyuyor, saatlerce aynanın karşısında güzel yüzünü seyretmekten baş alamıyordu. Bundan sonra da saatlerce kadınlarını önünde diz çöktürerek güneş ziyasında yapılmış altın demeti saçlarına, buğulu üzüm gözlerine taptırıyordu.” (85)
\end{abstract}

Kerim Sam'ın İmparatoriçe İren isimli romanından kısa bir süre sonra, 1948 yılında gazeteci, yazar ve romancı Murat Sertoğlu, Bizans’in Aşk İlahesi İmparatoriçe Teodora isimli romanını yayımlamıştır. 6. yüzyılda tiyatro dansçısı olarak başladığı yaşamını Bizans'a en parlak dönemini yaşatan İmparator Iustinianus'un (527-565) karısı ve imparatoriçe olarak sonlandırmış olan Teodora hakkındaki bu eser, üç ciltlik serinin ilk cildidir. Üçüncü cilt Teodora’nın Ölümü 1950, ikinci cilt Bizans Alevler İçinde 1956 ylında yayımlanmıştır. Sertoğlu'nun romanını yazmadan önce iyi araştırma yapmış olduğu ve tarihi olayları olduğu gibi aktarmaya çalıştığı anlaşılmaktadır³.

11 İmparator II. Romanos (956-963), 956 yll civarında bir meyhanecinin kızı olan ve imparatoriçe olarak Theohano adını alan Anastaso ile evlenmişti. II. Romanos, az bulunur güzellikte fakat tamamıla ahlak düşkünü ve ölçüsüz derecede haris olan Thephano'nun aşkına kapılmıştı. İmparator aşkı uğruna anne İmparatoriçe Helene bir kenara çekilmiş ve imparatorun beş kız kardeşi zorla manastıra gönderilmişti. II. Romanos'un genç yaşında ölümü devletin idaresi; küçük yaştaki oğulları ve her ikisi de sonradan imparator olacak olan II. Basileios (976-1025) ve VIII. Konstantinos'un (10251028) naibi olarak imparatoriçe Theohano'ya kaldı. Zeki Theophano kadın olduğu için devletin idaresinin ayaklanmalar ile elinden alınacağını biliyordu. Komutan Nikephoros Phokas ile anlaşma yaptı. Evlilikleri ile Phokas (963-969), iki genç prensin hamisi oldu. Ancak "çirkinliğin sınırlarını zorlayan, neredeyse iki katı yaşında, aşırı dinci Nikephoros" (Norwich 2013b, 159) ile evlenmesi zor durumda olduğunun kanıtıdır. Theophano, Phokas'a göre asil, genç ve parlak kumandan Çimiskes'in metresi ve yardımcısı oldu. 10-11 Aralık 969 gecesi Çimiskes’in suikast planına sarayı açarak yardım etti ve kocası imparator Nikephoros Phokas'ın yatakta öldürülmesini sağladı. İmparatorluk tahtına Ioannes Çimiskes (969-976) çıktı. Patrik Polyeuktos, yeni imparatora Çimiskes’in işlediği güanh için tövbe etmesini ve imparatoriçe Theophano’yu saraydan atmasını ve Phokas'ın katillerini cezanlandırmasını aksi takdirde kendisini kiliseye kabul edip taçlandırmayacağını açıkladı. Böylece Theophano’ya sürgün yolu gözüktü (Ostrogorsky 2015, 264-272; Diehl 1963, 114135).

12 Bizans imparatoriçesi tacını giyen ikinci Atinalı olan Irene (780, 797-802), olağanüstü güzel ancak entrikacı ve düzenbaz, hırslı kişiliği ile ve Bizans tarihinde işlenmiş en kötü cinayetlerden birinin faili olarak adını tarihe yazdırmıştır (Norwich 2013a, 297).

13 Teodora hakkında bilgilerimiz dönemin yazarı ve bizzat Teodora'nın yaşamına tanıklık etmiş olan 6. yüzyıl yazarı Prokopios’tan sağlanmaktadır. Prokopios'un Iustinianos ve Teodora’nın hükümdarlık dönemini anlattığı Bizans’ın Gizli Tarihi (2001) isimli kitabından Teodora'nın Hipodromda ayı bakıcısı Akasius’un üç kızından biri olduğu, küçük yaşlarından itibaren fahişelik yaptığını, şehvet düşkünü bir dansçı, acımasız bir imparatoriçe olduğunu, istediğini elde etmek için her yolu mubah gördüğünü, güzelliğini ve zekasını birleştirerek Iustinianus’un karısı olmayı başardığını öğreniyoruz (69-78, 99-112). Dönemin yazarı olması bakımından Prokopios'un Teodora hakkında yazdıkları bizim için çok değerlidir: "Onun çekici bir yüzü ve iyi bir vücudu vardı... Bakışları her zaman öfkeli ve sertti." (77) "Teodora'nın akl, fikri inatla ve sürekli olarak insanlara kötülük etmeye saplanmışt.”. (99) Bununla birlikte Prokopios'un eserinin acımasızlığ ön yargılı olduğunu da düşündürtmektedir. Prokopios'un eserinde Teodora hakkındaki Prokopios'un verdiği 
Rahat ve akıcı bir dille yazılmış eserinin Bizans’n Aşk İlahesi İmparatoriçe Teodora isimli ilk cildi, Teodora'nın hipodromda dansçılık yaptığı yılları ve İmparator Iustinos'un (518-527) yeğeni ve geleceğin Bizans İmparatoru Iustinianus'la tanışmasını ve onu elde etmek için yaptıklarını, ikinci cildi Bizans Alevler İçinde, Teodora'nın ve Iustinianus'un evliliklerini ve Teodora'nın iktidar hırsı uğruna göze aldıklarını, üçüncü cildi Teodora'nın Ölümü ise Teodora ve Iustinianus'un saltanat yıllarının acımasızlığını ve Teodora'nın son zamanlarını konu edinir.

Sertoğlu; son derece güzel ve zeki olan imparatoriçe Teodora'yı şehvetli, cinsellik düşkünü, acımasız ve kalpsiz ancak Bizans İmparatorluğu'nun en parlak dönemlerinden birinin kurucusu olarak tasvir eder:

"Teodora güzel bir kadındır. Bütün Bizans halkını çıldırtacak kadar güzel danslar biliyor. Fakat bütün meziyeti bundan ibaret. Vücudu güzel fakat kalbi çirkindir. Birçok insan ona aşık olabilir. Fakat o kendisini sevenlere aşk değil zehir veriyor." (1955, s. 124).

“Teodora'nın ne müthiş bir kadın olduğunu pek güzel biliyordu. Eğer istediğini yapmayacak olursa mutlak surette kendisinden müthiş bir intikam alacağını biliyordu” (1956, s. 107)

“Büyük Bizans kuruluyordu. Iustinianos'un muhalifleri, Teodora'nın siyaseti sayesinde birer birer ortadan kayboluyordu... Iustinianos'un hazırlamakta olduğu kanun kitabında ileri sürdüğü fikirlerin çoğu Teodora'nın idi...”(1956, s. 119)

Abdullah Kozanoğlu (1906-1966) tarafından 1964 yllında yayımlanan Arena Kraliçesi romanı da imparatoriçe Teodora'nın hayatını konu edinir. Türk edebiyatının tarihi roman türünün en ünlü temsilcilerinden ve en çok okunan tarihi roman yazarlarından biri olan Kozanoğlu, bu eserinde 532 yll Nika ayaklanması öncesi dansçı Teodora ve güçlü, kuvvetli, mert, herkesi yenebilen Uygur Türkü Ceberhan'ın maceralarını ve aşklarını anlatır.

Kozanoğlu'nun romanlarında; ulusçu ideoloji çerçevesinde oluşturduğu mert, cesur, gözü pek kahramanlarına aşık olan Bizanslı kadınlar, güzellik ve cilveleriyle ünlü, şehvetli kadınlardır. Bu kadınlar Türk erkeklerini seçip onlara aşık olduklarında, Türklerin üstünlüğüne vurgu yapılır. Arena Kraliçe'sinde de bu ideolojiye uygun olarak güzel, şehvetli, cinsellik düşkünü Teodora (imparatoriçe olmadan önce), Ceberhan'a yardım eder ve ona aşık olur. Bu eser, Dünya ve Türk Edebiyatında hakkında en çok roman yazılan Bizans İmparatoriçesi Teodora'nın ${ }^{14}$ Türk yazınındaki ilk biyografik romanı olması açısından da önemlidir. Teodora'nın hakkında en çok biyografik roman yazılan Bizans İmparatoriçesi olmasının nedeni kuşkusuz, renkli hayatıdır.

bilgilere karșın; Bizans tarihinde en önemli dönüm noktalarından biri olan ve Konstantinopolis’in büyük kısmının yandığ Nika İsyanı (532) sırasında kaçmak için hazırlanan Iustinianus'un karşısına çıarak onu durdurması ile imparatorun isyanı bastırabilmesi (Deihl 1963, 44-64; Ostrogorsky 2015, 67) güçlü kişiliğini yansıtmaktadır. Bizans'a en parlak dönemini yaşatan Iustinianos'un başarısında, kuşkusuz imparatoriçe olarak Teodora'nın da büyük katkısı olmuştur.

14 İmparatoriçe Teodora'nın Türk ve Dünya edebiyatında yer alan biyografik romanlarından bazıları: Duffy 2011, Wellman 2002, Potter 2015, Philips ve West 2006, Korber 2008, Thornton 2013, Ridici 2009, Gültaş 2008. 
Türk edebiyatında hakkında roman yazılmış bir başka Bizans imparatoriçesi 11. yüzyılda yaşamış Eudokia Makrembolitissa'dır ${ }^{15}$. Resimli Tarih Mecmuası'nda ${ }^{16}$ Bizans İmparatoriçeleri ile ilgili yazan ${ }^{17}$ tarih öğretmeni, yazar Yakup Özdemir tarafından 1977 yllında yayımlanan Bizans’nn Bahtsız Kraliçesi isimli eserde, imparatoriçe Eudokia, muhteşem güzellikte ancak bir o kadar acımasız, hırslı ve şehvet düşkünü bir kadın olarak sunulur: "Eudoksia odanın ortasında durmuş, o anda gözleri boy aynasında bütün dişi güzelliği ile görünen muhteşem haline takılmışt..” (15). "Kraliçe Eudoksia göz kamaştırıcı bir güzellikte odanın ortasında duruyordu.” (23) 1071'de Malazgirt Savaşı'nda Alparslan'a yenilen IV. Romanos Diogenis’in karısı Eudokia dişiliği ile ön plana çıkarılmıştır.

1977 yılından sonra Türk edebiyatında Bizanslı kadınların izleri 200oli yıllara kadar kaybolur. 2007 yılında Selim İleri Bizans İmparatoriçesi Irene'nin hayatını romanlaştırır. Bu eser Türk edebiyatında Bizanslı kadınların tasvirinde farklılık yaratır ${ }^{18}$.

\section{Selim İleri’nin "Hepsi Alev" romanı}

"Hüzünlerin, acıların, ayrılıkların, karşılıksız sevgilerin, yıkılışların” yazarı Selim İleri (Naci, 1990, s. 381), edebiyatın hemen hemen her türünde eser vermiş olmakla birlikte, romancı kimliğiyle öne çıkmış bir yazardır. (Mengi, 2012, s. 127). İleri, Hepsi Alev romanı ile Bizans İmparatorluğu'nun en güçlü kadınlarından biri olan İmparatoriçe Irene'nin (780, 797-802) hayatının bir dönemine odaklanmıştır.

İmparatoriçe'nin ağzından yazılan eserde; Kerim Sam'ın eserinden farklı olarak; kırgın, yorgun bir o kadar da gururlu bir Bizans kadını tasvir edilmiştir. Bir kadın olarak yasak aşkları, entrikaları ve hırslarından ziyade Bizans tarihinde önemli bir dönem noktasını gerçekleştirmiş, ikonoklazma dönemini19 sonlandırmış güçlü bir hükümdar olarak karşımızdadır Irene: "Yüzümdeki çizgilere baksalar, kaç dağ rüzgartyla, firtınayla, kasırgayla boğuştuğumu, hepsine boyun eğdiğimi anlayacaklar." (12)

15 İmparatoriçe Eudokia Makrembolitissa, kocası X. Konstantinos Dukas'ın (1059-1067) Mayıs 1067 yllındaki ölümü nedeniyle küçük oğulları Mikhail, Andronikos ve Konstantinos'un naibesi olarak tahta çıkmıştır (Zonaras, 2008: 120; Bryennios, 2008: 36, Psellos 1992: 219, Attaleiates 2008: 100). Çok akıllı bir kadın olan imparatoriçe, bütün idareyi bizzat kontrolüne almıştı. Psellos, büyük oğlu Mikhail’in imparatorluk idaresi hakkında yorum yapacak yaşta olmasına karşın tüm idareyi annesine bırakmasına anlam veremediğinden bahsetmektedir (221). Ölürken kocasına verdiği bir daha evlenmeme sözünü çabuk bozarak, ki Zonaras’a göre şehvete kapıldığı için değil, oğulları ve kendisinin hayatını ve iktidarını kaybetme korkusu ile "eylemci, savaşçlıkta sınanmış ve benzersiz bir güce sahip Romanos Diogenes ile evlendi ve onu imparator yaptı (122).

16 Resimli Tarih Mecmuası, akademik bir yazım tarzının dıșında sade ve anlassılır bir tarzda yazılmıs tarihi metinler aracılığıyla halk arasında tarihi konulara merak uyandırmak ve milli duyguları beslemek amacıyla yayımlanan Cumhuriyet döneminin uzun süreli ilk popüler tarih dergisidir. Ocak 1950 yılında ilk sayısını çıkartan dergi aralıksız 84 sayı yayımlayarak ilki gerçekleştirmiş̧tir (Karabulut 2019, s. 1042-1048).

17 "İmparatoriçe Öjeni ve Sultan Aziz", Mayıs 1950 S: 5 S. 172-174.

182007 yılından sonra imparatoriçe Teodora hakkında iki roman daha yayımlanır. 2008 yılında Ayhan Gültaş tarafından yayımlanan Kızıl Nefer Teodora ve 2009 yllında Radi Dikici tarafindan yayımlanan Theodora isimli eserlerin çok araştırılmadan, özensiz yazıldıkları fark edilmektedir. Ayhan Gültaş, romanının sonunda verdiği görselde Ravenna San Vitale Kilisesi’ndeki Teodora Mozaiği’nin “Ayasofya’daki Mozaiklerden biri” olduğunu yazmıștır. Üstelik Teodora’nın yanındaki hadımı, İmparator Iustinianos olarak tanıtmıştır. Radi Dikici'nin romanında ise girişteki "Yazarın Notu" bölümünde şu sözler dikkat çekmektedir: "İmparatoriçe Theodora'nın hayat hakkında, bu kitabın son bölümünde de göreceğiniz gibi, birçok biyografik eser yazılmıştır; ancak hayatının romanlaştırıldığı bir kitap henüz mevcut değildir. Elinizdeki yarı belgesel romanla, yalnız ülkemizde değil dünyada da bir ilk olmanın, Theodora hakknda yazılmış tek roman, yazın dünyamıza kazandırmanın mutluluğunu yaşıyorum." Dünyada ve Türkiye'de en çok hayatı romanlaştırılan kadınlardan biri olan Teodora hakkında kendisinin ilk romanı yazdığını ifade etmesi manidardır.

19 Sözlük anlamıyla "ikonaların kırılması" demek olan ikonoklazma (ikonakırıcılık), "Oyma putlar yapmayacaksın ve onlara tapınmayacaksın” diyen Musa'nın İkinci Emri’nin ilham ettiği bir harekettir. İmparator III. Leon (717-741) döneminde başlayan hareket, tüm imparatorlukta ikonaların toplatılıp yok edilmesini ve ikonalara tapanların cezalandırılmasını sağlamaya çalışmışıır. 
Irene, Atina'dan gelin getirildiğinde geleceğin imparatoru ve kocası olacak Leon, onun güzelliği, sarı saçları karşısında büyülenmişti. Bizans İmparatorluğu en sıkıntılı zamanlarını yaşıyordu. İkona²o karşıtlarının zaferi nedeniyle tüm Bizans'ta ikonalar toplanıp yok edilmekteydi. İkonseverler yenilmiş olsalar da gizliden gizliye ikonalara tapma devam etmekteydi. Özellikle kadınlar, kiliselerde saygı duydukları ve evlerinde en değer verdikleri eşyalar olarak tuttukları ikonalara tutkuyla bağlıydılar ${ }^{21}$. Bu kadınlardan biri de Irene idi.

İmparatoriçe olduktan sonra da bir ikonsever olduğunu gizleyen Irene güçlü bir kadındı. Kocası İmparator IV. Leon'un (775-780) döneminde etkisi altında olan imparatorluk, kocasının ölümü ile tamamen onun eline geçmişti. 780-797 yılları arasında oğlu VI. Konstantinos'un naibi olarak, 797-802 yılları arasında da tek hükümdar olarak Bizans İmparatorluğu'nu yönetmiş ve ikonoklazmanın ilk döneminin sona ermesini sağlamıştı (Ostrogorsky, 2015, s. 166-170; Diehl, 1963, s. 65-93; Runciman, 1978, s. 101-118). Irene, kendi adına Bizans İmparatorluğunu yöneten ve "basilissa" unvanını alan ilk kadındı22. Naipliği ve imparatorluğu döneminde sikkeler üzerindeki tasviri iktidarının gücünün kanıtı olarak görülmektedir (Canko, 2017, s. 116-118). Irene'nin tek başına hükümdar olduğu dönemde bir kadın olarak askeri deneyiminin olmaması ve birçok rakibinin olması ayrıca bir ikon sever olması kuşkusuz onun çok dikkatli ve planlı hareket etmesini gerektirmişti. Güçlü, başarılı ve hırsh imparatoriçe; kuşkusuz yalnızlıklar, hüzünler ve pişmanlıklar yaşamıştı. Selim İleri, imparatoriçenin insani yönüne odaklanırken onun büyük bir imparatorluğu yönetmiş bir hükümdar imparatoriçe olmasından ziyade bir insan ve bir kadın olduğunu vurgulamaktadır:

"Bizans'ın karşısında daima dimdik ve muzafferdim. Fakat kendi kendime kaldığımda... Kendi kendime kaldığımda, yapayalnız kapkaranlık, var olmanın sırrını çözememiş. Gün günden ıssız bir yürekle...”(21)

İleri, Irene'nin bir ikonsever olarak ikonoklazma döneminde iktidarını korumak için neler yaptığına ve asıl önemlisi bu yaptıkları ile neler hissettiğine odaklanıyor. Irene, romanın ilk sayfasında hayatının sonunda Lesbos adasına sürgüne gönderilirken bile duygularını sakladığını ifade ediyor: "Yüzüm ifadesiz, yüzümü ifadesiz kılmıştım. Duygulartm anlayamadılar” (9). Irene, Bizans İmparatorluğu'nun acımasız iktidar savaşlarında bir kadın olarak hislerini kimseye belli etmemesi gerektiğini biliyor. Oğluna ve kocasına bile: "Ebedi Şehir'deki yalnızhğın kimseye anlatamıyordu, kocası Leon'a bile." (29) Kocası ve oğlu ise ona göre güçsüz imparatorlardı, Bizans ise köhne, kokuşmuş bir imparatorluktu (38): "Kalbimi herkesten saklayacaktım, bedenimin efendisi' kocam en başta. Bedenimin efendisi mi?! Bizans'in en zavall ahlakl...”(47)

Bizans İmparatorluğu'nun ilk kadın hükümdarı, ikonoklazmanın ilk dönemini sona erdiren imparatoriçe Irene, kendi çocuğunun katili olarak da tarihe adını yazdırmıştır. İmparator IV. Leon'un ölümünün ardından küçük yaştaki oğlunun naibi olarak tahta çıkan Irene, oğlu büyüdüğünde tahttı ona

$20 \quad$ İkona; İsa, Meryem ve azizlerin kendilerinin ve yaşamlarının canlandırıldığı taşınabilir nitelikteki levhalardır.

21 İkonoklazma döneminin en başında bir asker Büyük Saray'daki Khalke Kapısı'nın üzerindeki İsa imgesini yıkmak için gönderildiğinde Azize Theodosia'nın önderliğindeki bir rahibe grubunun askerin çıktığı merdiveni aşağı çektiği söylenmektedir. Bu kadınlar III. Leon'nun emri ile idam edildiklerinde ilk ikonofil sehitler olmuşlardır. Diğer bir ikonofil (ikonsever) rahibe Mantineonlu Azize Anthousa yakılan ikonaların korlarının vücuduna dökülmesiyle işkence görmüştür. Ayrıca, kocalarının ölümünden sonra ikonaları yeniden canlandıran iki imparatoriçe olmuştur: 787'de Irene ikonaları geri getiren İkinci Nikea Konsili'ni toplamış; 843'de ikonoklast imparator Theophilos'un dul karısı Theodora, Ortodoks Kilisesi'nin resmi doktrini olarak heykellere tapmanın kalıcı olarak geri getirilmesine başkanlık etmiştir (Talbot 1997, 133) İmparatoriçe Irene, Theodora, Azize Theodosia ve Anthousa'nın öyküleri kuşkusuz, kadınların ikonalara, onları korumak için bağımsız hareket edecek kadar bağlı olduklarını göstermektedir.

22 Bizans imparatorluğunu kendi adına yöneten üç imparatoriçe olmuştur: Irene, Zoe ve kardeşi Theodora. Zoe ve Theodora babalarının imparator olması dolayısıyla imparatorluk ailesine mensup olmalarından dolayı iktidar sahibi olmuslardır. Ancak Irene, imparatorluk ailesinden olmamasına karşın iktidar hırsı ve azmi nedeniyle Bizans İmparatorluğu’nun ilk kadın hükümdarı olmayı başarmıştır. 
teslim etmemişti. Oğlu VI. Konstantinos'un birkaç girişimi de başarısız olunca oğlunun gözlerinin doğduğu mor odada kör edilmesi emrini vermişti (Gregory, 2008, s. 197). Irene, Hepsi Alev'de bunun nedenini de bize açıklıyor:

"Suçlarım olmasaydı zaferlerim de olmayacaktı. İmparatorluğun kadınlarından beklenen, perde arkasından hüküm sürmek, annelikle yetinmektir. Gönül indirmedim. Perdeyi yırtıp attım. Omuzlarıma yüklenen anneliği reddettim.” (18)

Irene, iktidar hırsının belki de hayatta kalma güdüsünün anneliğine üstün geldiğini de itiraf ediyor: "Ylkılıp gitmemek için karanlık çareler aramak zorundaydım." (38). Irene'nin iktidar uğruna çocuğunu öldürttüğü gerçeğine İleri, ailenin hiç olduğu, kan bağının da bir yalan olduğunu söyleyerek (Özhan, 2010, s. 30) anlam yükler. Ancak iktidardayken bile huzuruna çıan insanların imparatoriçe Irene'yi değil, çocuğunun katili Irene'yi gördüklerini de itiraf ederek imparatoriçe kimliğini ön plana çıkarmaya çalışır: "Benden... oğlunun gözlerine mil çektirtmiş anneden nefret ediyor. Basileus'u görmüyor da anneyi görüyorlar.” (179).

Selim İleri, Irene karakteri ile iktidardaki insanların; acımasız, güçlü görünüşüne karşlık; inançları uğruna ailesini bile yok sayarken yalnız ve sevgisiz olduklarına vurgu yapıyor: "Başka insanların kalbinde evlatları için acı olabilir. Sevgi olabilir. Benimkinde olmadı. Kimse için olmad.." (21). "İleri, yalnızlık izleğinden geçirdiği kadınlarıyla hüznün ve sitemin yazarı olarak ifade edilirken" (Özhan, 2010, s. 30), İstanbullu Irene'nin de büyük bir İmparatorluğu yönetmiş bir kadın hükümdar olsa da bir insan ve bir kadın oluşuna odaklanıyor. Türk edebiyatında ilk kez Selim İleri Hepsi Alev romanı ile bir insan ve imparatoriçe olarak Bizansh bir kadının yaşadıklarına, başarılarına, acılarına, sevinçlerine, savaşlarına ve hüzünlerine odaklanmıştır:

“Gözyaşı döktüm. Kendim için. Teodora’nın küçülüşleri için. Çünkü Bizans’a hükmetmiş.... Gözyaşı döktüm binlerce gözyaşı. Ama neye yarar? Bayağılığın doruklarındayken iktidarımın da doruklarındaydım. Bizans'ın bana oynayacağı oyunları aynı oyunbozanlıkla durdurdum... İktidarla pespayelik, çirkeflik arasındaki o yakın, kardeş ilişkiyi çoktan fark etmiştim. Kişisel inançlarınızı, ülkülerinizi, öz değerlerinizi, benliğinizi yitirdikçe yükseliyorsunuz. Uğrunda sürüklendiğiniz iktidar bile size tapıyor. Aldanışım, iktidarı ele geçirdikçe, iktidarı avucumda tuttukça 'yüksek sanat'a kavuşabileceğim şansı! Büyük aldanış.” (129)

\section{Sonuç}

Türk edebiyatında Bizans imparatoriçeleri, tarihi romanlardan ziyade tarihi biyografik romanlarda temsil edilmişlerdir. Bu makalede incelenen beş eserden ikisi İmparatoriçe Teodora, ikisi Irene ve biri Eudokia’nın konu olduğu romanlardır. İmparatoriçeler Teodora ve Irene Bizans İmparatorluğu'nun kilit dönemlerini başarı ile yürütmüş ve imparatorluğun devamını sağlamış büyük karakterlerdi. Renkli kişilikleri ve hayat tarzları onların merak edilmesini ve Türk edebiyatına en çok konu olan Bizans kadınları olmalarını sağlamıştır.

Bizans imparatoriçelerinin biyografilerini yazan Kerim Sam, Murat Sertoğlu, Abdullah Ziya Kozanoğlu ve Yakup Özdemir’in eserlerinde dönemin ulusçu yaklaşımının etkisi yoğun olarak hissedilmektedir. Selim İleri'ye kadar olan tüm bu eserler; Bizans imparatoriçelerini, bir imparatorluk üyesi olarak Bizans tarihine katkılarından ziyade kadın olarak dış görünüşlerinin güzelliği, acımasız ve sert tarafları ile şehvet düşkünü, cinsellik tutkunu olarak tasvir etmişlerdir. Türk edebiyatında ilk kez Selim İleri, bir insan ve imparatoriçe olarak Bizanslı bir kadının yaşadıklarına, başarılarına, acılarına, sevinçlerine, savaşlarına ve hüzünlerine odaklanmıştır. 
Selim İleri’nin Hepsi Alev romanında, Irene'nin ağzından iktidarının bitiminde sürgüne gönderilirken içinden geçenlere tanık oluyoruz. Sanki kendi kendine konuşurken onu sadece biz duyabiliyoruz, Onun imparatoriçe olmasının dışında bir insan, bir kadın olduğunu sadece biz biliyoruz. Okuyucuda tarihin derinliklerine gömülmüş insani bir sırra sadece kendinin sahip olduğu hissini yaratabilmesi yazarın önemli bir başarısıdır. Bu eser, büyük ve yüce bir imparatoriçenin hayatının sonunda günah çıkarma metni gibidir. Bizanslı kadınlar algısının Türk edebiyatında büyük ölçüde değiştiğinin belgesidir.

\section{Kaynakça}

Attaleiates M. (2008). Tarih. Bilge Umar (Çev). İstanbul: Arkeoloji ve Sanat Yayınları.

Belge M. (2009). Genesis “Büyük Ulusal Anlatı” ve Türklerin Kökeni. İstanbul: İletişim Yayınları.

Bryennios N. (2008). Tarihin Özü. Bilge Umar (Çev). İstanbul: Arkeoloji ve Sanat Yayınları.

Canko D.M. (2016). "Bizans Dünyasında ve Sanatında Kadının Yeri”. Ege Üniversitesi Sosyal Bilimler Enstitüsü Yayınlanmamış Doktora Tezi. İzmir.

Canko D.M. (2017). “Sikkelerin Işı̆̆ında Bizans’ta İmparatoriçe İmgesi ‘780-1204”, Art Sanat 8/2017, 113-137.

Çeri B. (1992). “1923-1938 Dönmei Türk Romanında Kadın”. Hacettepe Üniversitesi Sosyal Bilimler Enstitüsü Yayınlanmamış Yüksek Lisans Tezi. Ankara.

Diehl C. (1963). Byzantine Empress. New York.

Dikici R. (2009). Theodora. İstanbul: Remzi Kitabevi.

Duffy S. (2011). Theodora: Actress, Empress, Whore, Little. Brown Book Group.

Gregory T. (2008). Bizans Tarihi. Esra Ermert (Çev). İstanbul: Yapı Kredi Yayınları.

Gültaş A. (2008). Kızıl Nefer Teodora. İstanbul: Yakamoz Yayınları.

Gürsel N. (2010). Boğazkesen Fatih’in Romanı. İstanbul: Doğan Kitap.

Has Er (2000). Tanzimat Devri Türk Romanında Kadın kahramanlar. Ankara: Atatürk Kültür Merkezi Yayınları.

İleri S. (2007). Hepsi Alev. İstanbul: Doğan Kitap.

Karabulut, Sezen, (2019). “Cumhuriyet Dönemi’nin Uzun Süreli İlk Popüler Tarih Dergisi: Resimli Tarih Mecmuası”. Belgi Dergisi, C.2, S.17, Pamukkale Üniversitesi Atatürk İlkeleri ve İnkllâp Tarihi Araştırma ve Uygulama Merkezi Yayınları, Kış 2019/I, S. 1042-1071.

Korat G. (2012). Rüya Körü. İstanbul: İletişim Yayınları.

Korber T. (2008). İmparatoriçe. İstanbul: Literatür Yayıncılık.

Kozanoğlu A.Z. (1946). Battal Gazi Destanı. İstanbul: Türkiye Yayınevi.

Kozanoğlu A.Z. (1964). Sarı Benizli Adam. İstanbul: Atlas Kitabevi.

Mengi N. (2012). "Selim İleri’nin Romancllı̆̆ ve Türk Romancılığındaki Yeri”. Folklor/edebiyat, C: 18, S: 71, 2012/3. 127-141.

Millas H. (2000). Türk Romanı ve “Öteki” Ulusal Kimlikte Yunan İmajı. İstanbul: Sabancı Üniversitesi Yayını.

Naci F. (1990). 100 Soruda Türkiye'de Roman ve Toplumsal Değişme. İstanbul: Gerçek Yayınevi.

Norwich J.J. (2013a). Bizans I Erken Dönem. İstanbul: Kabalcı Yayınevi.

Norwich J.J. (2013b). Bizans II Yükseliş Dönemi. Fikret Işıltan (Çev). İstanbul: Kabalcı Yayınevi.

Ostrogorsky G. (2015). Bizans Devleti Tarihi. Ankara: Türk Tarih Kurumu Yayınları. 
Özdaracı Arslan Ö. (2010). “Türk Romanında Kadın (1872-1900)”. Kırıkkale Üniversitesi Sosyal Bilimler Enstitüsü Yayınlanmaış Doktora Tezi.

Özdemir Y. (1977). Bizansın Bahtsız Kraliçesi. İstanbul: Çağdaş Yayınevi.

Özhan Z. (2010). "Selim İleri'nin Romanlarında Kadın". Cumhuriyet Üniversitesi Sosyal Bilimler Enstitüsü Yayımlanmamış Yüksek Lisans Tezi. Sivas.

Prokopios (2001). Bizans'ın Gizli Tarihi. Orhan Duru (Çev.). İstanbul: Türkiye İşs Bankası Yayınları.

Psellos M. (1992), Khronographia, Işın Demirkent (Çev). Ankara: Türk Tarih Kurumu.

Phillips R, West J. (2006). Who in the World was the Acrobatic Empress?: The Story of Theodora. W. W. Norton \& Company.

Potter D. (2015). Theodora: Actress, Empress, Saint, Oxford University Press

Refik A. (2003). Bizans İmparatoriçeleri. İstanbul: Oku Yayınları.

Runciman S. (1978). “The Empress Irene the Athenian” D. Baker (ed), Medieval Women, Oxford, 101118.

Sağllk Ş. (2002). "Tarihi Popüler Türk Romanlartnda Yüceltilen Bir "Değer" Olarak "Türk” Kimliği”. Ilmi Araştırmalar 14. İstanbul.

Sakaoğlu N. (1993), "Altınay, Ahmet Refik”, Dünden Bugüne İstanbul Ansiklopedisi C: 1, Kültür Bakanlığı ve Tarih Vakfi Yayınları, 1993, 218-220.

Sam K. (1946). İmparatoriçe İren. İstanbul: Gün Basımevi.

Sertoğlu M. (1950). Teodora'nın Ölümü. İstanbul: Güven Yayınevi.

Sertoğlu M. (1955). Bizansın Aşk İlahesi İmparatoriçe Teodora. İstanbul: Güven Yayınevi.

Sertoğlu M. (1956). Bizans Alevler İçinde. İstanbul: Güven Yayınevi.

Şeker A. (2017). "Türk Romanında Toplumsal Cinsiyet Açısından Kadın Temsillerine Yönelik Sosyolojik Bir Çözümleme”. Uluslararası Sosyal Araştırmalar Dergisi. C: 10, S: 54, 641-652.

Talbot A.M. (1997), "Women", The Byzantines, G. Cavallo (Ed). University of Chicago Press, 117-143.

Thornton S. (2013). The Secret History: A Novel of Empress Thedora. Berkley.

Uğur V. (2013). 1980 sonrası Türkiye’de Popüler Tarihi Roman. İstanbul: Koç Üniversitesi Yayınları.

Zonaras I. (2008). Tarihlerin Özeti. Bilge Umar (Çev). İstanbul: Arkeoloji ve Sanat Yayınları.

Wellman P. (2002). Bizans Fahişesi Theodora. İstanbul: Tümzamanlar Yayıncılık. 